\title{
THE DISPUTES OF RATÉB SIRIBÈE IN ACEH
}

\author{
Misri A Muchsin, Abdul Manan, Rahmad Syah Putra \\ Fakultas Adab dan Humaniora UIN Ar-Raniry \\ Jl. Syeikh Abdul Rauf Darussalam Banda Aceh, 23111 \\ e-mail: misrimuchsin@yahoo.com, abdul.manan@ar-raniry.ac.id, rahmat.sp91@yahoo.co.id
}

\begin{abstract}
Abdul Hadi
Sekolah Tinggi Agama Islam Tgk. Chik Pante Kulu, Banda Aceh J1. Teuku Nyak Arief Kopelma Darussalam, Banda Aceh, 23111 e-mail: abdul.hadi@yahoo.com.
\end{abstract}

\begin{abstract}
This study discusses the foundation of Sufi tenet developed by Shaykh Amran Waly and the communities' response to the integration of the tenet - the Study Council of Sufism Tawhîd (MPTT) and ratéb siribèe (one-thousand dzikr)within the northern and eastern Aceh, Indonesia. Qualitative approach was implemented as the observation, in-depth interviews and documentation studies were due to collect the data. MPTT and ratéb siribèe as its integration aim to restore the grandeur of Acehnese people in the past. However, the tenet was responded in many ways by the communities. Some considered that MPTT and ratéb siribèe could act as a means of practicing Sufism, while the others assumed that the teachings developed were deviant since those contain the style of Ibn al-Arabî and al-Jîlî Sufism.
\end{abstract}

\begin{abstract}
Abstrak: Penelitian ini mengkaji fondasi ajaran tauhid-tasawuf yang dikembangkan oleh Shaykh Amran Waly. Penelitian ini juga menelaah respons masyarakat utara dan timur Aceh terhadap integrasi dari ajaran tersebut-Majelis Pengkajian TauhidTasawuf (MPTT) dan ratéb siribèe (zikir seribu). Pendekatan kualitatif diimplementasikan dengan observasi, wawancara mendalam, dan studi dokumentasi sebagai instrumen pengumpul data. Hasil penelitian menemukan bahwa ajaran tersebut berdasarkan dari gaya sufisme yang dikembangkan oleh Shaykh 'Abdul Karîm al-Jîlî yang pernah dianggap bidah. MPTT dan ratéb siribèe sebagai integrasi ajaran tersebut memiliki tujuan untuk mengembalikan kejayaan rakyat Aceh pada masa lalu. Namun, berbagai respons muncul dari kalangan masyarakat. Beberapa menganggap MPTT dan ratéb siribèe dapat menjadi media untuk melatih ajaran sufisme, sementara pihak lainnya menganggap ajaran tersebut sesat karena mengandung gaya sufisme dari al-'Arabî dan al-Jîlî.
\end{abstract}

Keywords: Amran Waly, MPTT, ratéb siribèe, sufism, tawhî̀d 
MIQOT Vol. 45 No. 1 January-June 2021

\section{Introduction}

Aceh is an area in Southeast Asia that has significant role upon the development and dissemination of Islam. During its glorious era, Aceh was one of great Islamic kingdoms in the world, particularly between 16th and 17th century. The glory of this kingdom covered economic, military, politic, science, culture, and religion. ${ }^{1}$ In the religious aspect, the Islamic tenet developed in Aceh was not only in 'aqîdah (faith) and fiqh (jurisprudence), but also on Islamic mystical tenet, or widely known as Sufism. ${ }^{2}$

Regarding the development of Sufism in Aceh, many dynamics had been occurred. ${ }^{3}$ Between 16th and 17th century, there was Sufism called wahdah al-wujûd taught by Hamzah Fansuri, ${ }^{4}$ which was an adaptation of similar tenet introduced by Ibn al-Arabî in 560-638 $\mathrm{Hijri}^{5}$; in Indonesia, it was introduced by Syamsuddin as-Sumatrani. ${ }^{6}$ During that time, the tenet was prohibited by Nuruddin ar-Raniry, a muftî (advisors on religious field) of the Kingdom of Aceh during the reign of Sultan Iskandar Tsani and Sultanah Safiattuddin. ${ }^{7}$ Nuruddin was an Islamic scholar practiced the Sufism tenet of wahdah al-syuhûd as an opposition of aforementioned Sufism metaphysics, wahdah al-wujûd. This tenet was introduced by Muhammad Yamani (Ahl al-Sunnah wa al-Jamâ'ah), which in Aceh was developed by Nuruddin ar-Raniry and Shaykh Abdurrauf as-Singkili (Syiah Kuala). ${ }^{8}$ Ar-Raniry even decreed to catch and gave death penalty toward the followers of wahdah al-wujûd. Books regarding its tenet even were burnt down.

After the era of Syiah Kuala, Kingdom of Aceh gradually deteriorated. There were no great Islamic scholars as Hamzah Fansuri, Syamsuddin as-Sumatrani, Nuruddin arRaniry, and Syiah Kuala, who could write great Islamic books in Fiqh and Sufism. In recent days, even though the Sufism still develops in Aceh, it is never as great as in the era of 16th

${ }^{1}$ Arskal Salim, "'Sharia from below' in Aceh (1930s-1960s): Islamic Identity and the Right to Self determination with Comparative Reference to the Moro Islamic Liberation Front (MILF)," Indonesia and the Malay World 32, no. 92 (2004): 80-99; David Kloos, "Aceh: History, Politics and Culture," Pacific Affairs 86, no. 1 (2013), 193-95.

${ }^{2}$ Wasino et al., "A Historical Perspective of Sufism Networking in Asia: From India to Indonesian Archipelago," PalArch's Journal of Archaeology of Egypt/Egyptology 17, no. 3 (2020), 761-74.

${ }^{3}$ Ja'far Ja'far, Gerbang Tasawuf: Dimensi Teoretis Dan Praktis Ajaran Kaum Sufi (Medan: Perdana Publishing, 2016); Ja'far Ja'far, Warisan Filsafat Nusantara: Sejarah Filsafat Islam Aceh Abad XVI-XVII M (Banda Aceh: PeNA, 2010).

${ }^{4}$ Syaifan Nur, "Dialektika Filsafat Islam Sufistik Wujuddiyah Di Indonesia," Refleksi: Jurnal Filsafat Dan Pemikiran Islam 17, no. 1 (2017), 43-60.

${ }^{5}$ Musliadi, Abuya Syekh Muda Waly Al-Khalidy (1917-1961 M) Syekhul Islam Aceh: Tokoh Pendidikan dan Ulama Arif Billah (Banda Aceh: Yayasan PeNa, 2017), 32.

${ }^{6}$ Firdaus, "Meretas Jejak Sufisme Di Nusantara," Al-Adyan: Jurnal Studi Lintas Agama 13, no. 2 (2018), 303-37.

${ }^{7}$ Rusdiyanto and Musafar, "Ajaran Wujudiyah Menurut Nuruddin Ar-Raniri," Potret Pemikiran 22, no. 1 (2018), 1-10.

${ }^{8}$ Musliadi, 27. 
and 17th centuries. While the followers of Sufism order still exist in great number, the essence and life quality of them are different to the pervious era. This is inversely proportional compared to the implementation of Sharia law since 2001 in Aceh. Even the half of the Acehnese people admitted that it was not realized in accordance with the law itself. It concerned more on the physical matters, particularly the way of dressing, gambling, sexual intercourse, and so the like. In fact, the nature of Sharia law should be embedded within every daily activity of the communities. ${ }^{9}$

Nevertheless, the Sufism orders as Naqsyabandî, Syattariyah, and any other major order, still exist within Acehnese people recently. The Syattariyah, for example, dynamically plays a significant role in the social and political activities of people in the regency of Nagan Raya, Aceh. ${ }^{10}$ However, they merely exist within the community of dhikr. In previous time, the Sufism tenet was not limited within such ways, yet the tenet lived and became guidance for people to be acquainted to Allah, the Almighty. Even the literature in Aceh during previous time was influenced by such tenet, which led people to reach the condition of al-Insân alKâmil (the perfect human being). Such condition represents the great shift upon Islamic Sufism in Aceh on the tenet and practices. Nowadays, Sufism becomes a way for people to get peace and to get rid of daily bustle. In modern era, Sufism is an instant way to remember Allah. On the other hand, there are arguments among Islamic scholars regarding the practices of Sufism. Since there are many Sufism orders as the tenet is developed within the community of dhikr. In Aceh, it is established and led by charismatic scholar, thus, each community has certain leader. Such condition sometimes leads to a debate among different followers of certain orders; the followers of an order may argue to the existence of another one. Moreover, such community has influences toward people in Aceh.

The condition triggered the clash of people from different order in several area of Aceh. When a certain way of dhikr is taught and is developed by certain community, the other community may oppose it. In some cases, the other communities may announce fatwa (decreed), that the other community and its practices is deviant and is prohibited. As an instance for such case was, the existence of MPTT led by Shaykh Amran Waly, who was a son of an Acehnese charismatic scholar, Shaykh Abuya Muda Waly al-Khalidy. The case occurring in 2009 indicated the resistance of people toward this community of dhikr. The Islamic scholars in Aceh even announced a fatwâ prohibiting this community and its tenet, which oddly was supported by another son of Shaykh Muda Waly, Djamaluddin Waly. However, this tenet had been disseminated across Aceh, including in the area of West Aceh, South Aceh, Banda Aceh, Great Aceh, East Aceh, North Aceh, Java, and Sulawesi, even

${ }^{9}$ Abdul Manan and Fauzi Ismail, Syari'at Islam di Aceh: Realitas dan Respon Masyarakat (Banda Aceh: Ar-Raniry Press, 2014), p. 106.

${ }^{10}$ Abdul Manan, "The Influence of Tarekat Syattariyah toward Political and Social Aspects in the Regency of Nagan Raya, Aceh-Indonesia," International Journal of Advanced Research 5, no. 7, 2017. 
in some parts of Malaysia, Brunei Darussalam, and Thailand. This order even had established an international level of muzakarah (Islamic Ruling Discussion) discoursing the Tawhîd and Tashawuf within Southeast Asia countries. ${ }^{11}$ During that time, the Council of Islamic Scholars (MPU) in North Aceh, the Association of Islamic-traditional-school Teachers (HUDA), and the Board of Islamic Scholars of Aceh (MUNA) opposed MPTT. The majority of Islamic Scholars in Aceh accused its founder spreading the tenet of wahdah al-wujûd (apotheosis), which was prohibited by most Sunni scholars. ${ }^{12}$ This case was one of many similar cases occurring in Aceh. Uniquely, this case occurred within the community of dayah (Islamic conservatives). Commonly, such conflict occurred between the communities of dayah and Muhamadiyah (Islamic moderates). Nowadays, the conflict occurs between the communities of dayah and salafi (Islamic traditionalists). Thus, the case in 2009 became unique since it occurred within the community of dayah.

Considering this perspective, most Islamic scholars in Aceh are afraid that if MPTT develops within society, there will be political shift. If this condition continues, the disintegration of people may occur, thus, a deep and comprehensive study is necessary in order to find the solution for this dilemma. Therefore, the integration of the Sufism tenet developed by Amran Waly and the responses of the communities towards the tenet were studied, thus, the actual condition towards this issue could be examined. Not only did this study report the result, it also might suggest appropriate actions that could be taken.

\section{Methodology}

This descriptive study deployed a qualitative approach studying the problem and obtaining a deeper meaning about the communities' responses to MPTT in the North Aceh, Bireuen and East Aceh. Methodologically, it implemented a descriptive analysis model to portray and discuss the responses of the selected purposive samples. Several procedures were applied, namely conducting preliminary study, preparing initial related research information, interviewing the chosen informants - influential figures involved in MPTT in the research location, and analyzing the data obtained. Data-collection techniques used were observation, interview, and documentation. Data analysis in the field included recording data, coding, and temporary interpretations of various information obtained at each step of the research activity, which was based on the analysis was done on the basis of Miles and

${ }^{11}$ Syadidul Kahar, "Dynamics of the Intellectual Tradition of Ulama Dayah Aceh," Lakhomi Journal Scientific Journal of Culture 2, no. 1 (2021): 46-53; Serambi News, "Bangkitnya Ajaran Kesufian Nusantara," Serambi News, 2017.

${ }^{12}$ Moch Nur Ichwan, "Neo-Sufism, Shari'atism, and Ulama Politics: Abuya Shaykh Amran and Tauhid-Tasawuf Movement in Post-Conflict Aceh," in Islam, Politics and Change: The Indonesian Experience After the Fall of Suharto (Leiden: Leiden University Press, 2016), pp. 1-2. 
Huberman's qualitative data analysis: data reduction, data display, and conclusion drawing. ${ }^{13}$ Those were done approximately in six months.

\section{Results and Discussion}

Amran Waly had developed al-Jîlî Sufism and integrated into a social organization named MPTT and ratéb siribèe as its practical remembrance. The foundation of both and the communities' responses towards the integration of the developed tenet are depicted below.

\section{The Foundation of MPTT and Ratéb Siribèe}

Historically, the foundation of MPTT as a social organization was originated from concerns upon various imbalances experienced by contemporary Muslims, particularly in Aceh. According to Amran Waly, the current condition of Aceh is viewed to be inversely proportional compared with the glorious Aceh in the past. ${ }^{14}$ The magnificent condition of Aceh in the past was presumably realized by the unity of 'ulamâ, umara (Islamic leaders) and Acehnese people who had the same concept and practiced the teachings of monotheism and Sufism. ${ }^{15}$ This led Amran Waly to restore the previous greatness and glory of Acehnese people by establishing an organization to conduct religious social activities, raise awareness of the communities toward Islamic teachings and re-promote Tawhîd and Sufism as the real power of Aceh.

Patterning the true monotheism, the presence of MPTT is also expected to improve and carry out good deeds and noble morals. Not only will the people obey Allah, the Almighty, they also will be nurtured to feel Him in their heart until they die. As a result, these individuals can practice the Islamic teachings as a mercy in achieving happiness in both the world and hereafter. ${ }^{16}$ Amran Waly believed that Sufism was required to have a perfect monotheism. Sufism could eliminate khafi (hidden) shirk, while monotheism only could eradicate jail (visible) one. The point of Sufism itself is an effort to train the soul to persevere in worship

${ }^{13}$ Matthew B. Miles and A. Michael Huberman, An Expanded Source Book: Qualitative Data Analysis, 2nd ed. (California: SAGE, 1994).

${ }^{14}$ The glorious Aceh refers to the period of the Kingdom of Aceh Darussalam under the reign of Sultan Iskandar Muda. In that moment, the Acehnese people practiced the Islamic teachings and tasawwuf. Besides, Islamic scholars and muftî of the kingdom had their tasawwuf framework as the first tasawwuf teachings in Indonesia.

${ }^{15}$ Amran Waly al-Khalidy, personal communication, 21 March 2020.

${ }^{16}$ Amran Waly Al-Khalidy, "Aceh, Masyarakatnya, dan Langkah-langkah yang Diperjuangkan dalam Ajaran Tauhid Tasawuf bagi Masyarakat," in Maulid Nabi Besar Muhammad SAW 1437 (Pawoh, 2016), pp. 3-4. 
and return it to divine laws. This means that monotheism and Sufism should be combined. Both should not be separated as believed and practiced by 'ulamâ. ${ }^{17}$

The ideas of the actualization upon the classical Sufism were then carried out by Amran Waly by establishing an organization called MPTT to advance his movement on the teachings of Tawhîd-Tashawuf. It was established on 21 May 2004 based on Notary Legal Entity of Great Aceh, which was approved by Mukhsin in the Notarial Deed No. 14 of 2004. ${ }^{18}$ In that legal approval, it was stated that MPTT is one of 'organizations' headquartered in the sub-district of Labuhan Haji, South Aceh, Aceh. Like other organizations, MPTT is led by a general chairperson, which in this case, it is positioned by Amran Waly himself. By having Islamic foundation, the philosophy of Pancasila and the 1945 Constitution, it could have branches of representatives in other areas throughout Indonesia. ${ }^{19}$

As an organizational forum of Sufism, MPTT is expected to be a center to assembly 'ulamâ', umara, and ummah (Islamic communities) from various elements and parties. In addition to holding religious activities, MPTT is aimed to maintain the unity and integrity of the nation throughout cooperation and partnerships with the government, community groups, social organizations, educational institutions, and the whole societies. ${ }^{20}$

Moreover, it was recorded as an official organization having another legal entity issued by the Ministry of Law and Human Rights. ${ }^{21}$ Therefore, with that legalization, MPTT can legally conduct studies, education, teaching, counselling, dissemination, and practices of Islamic 'aqîdah comprehensively, which are in accordance with the Sharia and Sunnah of the Prophet Muhammad PBUH (peace be upon him). As a note, those are put in an 'ubudiyah (servitude) framework to worship Allah, the Almighty, love human beings, realize welfare, and achieve the happiness in the world and hereafter. ${ }^{22}$ Amran Waly has a strong commitment to unite ummah in any level of ages. He is accepted by many circles since he possesses communicative and moderate method and style of propaganda. MPTT is one of the unifying media and attracts people to prepare themselves in afterlife by practicing monotheism and Sufism. ${ }^{23}$

Meanwhile, ratéb siribèe is a practical method in MPTT, which was initiated by Amran

${ }^{17}$ T. Lembong Misbah, Gerakan Dakwah Sufistik: Majelis Pengkajian Tauhid-Tasauwuf Abuya Syeikh Amran Waly al-Khalidy di Aceh (Yogyakarta: UIN Sunan Kalijaga, 2016), p. 116.

${ }^{18}$ MPTT, "Notarial Deed of the Establishment of Majelis Pengkajian Tawhid Tasawwuf," Pub. L. No. 14 (2004), p. 1.

${ }^{19}$ MPTT, pp. 3-4.

${ }^{20}$ MPTT, pp 9-10.

${ }^{21}$ MPTT, "Ministerial Decree of the Establishment of Majelis Pengkajian Tawhid Tasawwuf" (2016).

${ }^{22}$ MPTT, Notarial Deed of the Establishment of Majelis Pengkajian Tawhid Tasawwuf, pp. 3-4.

${ }^{23}$ Serambi News, "Menyatukan Ummat Melalui Tauhid dan Tasawuf," Serambi News, 2017, https://aceh.tribunnews.com/2017/08/14/menyatukan-ummat-melalui-tauhid-tasawuf. 
Waly to eliminate anxiety and make people aware that making contact with Allah, the Almighty, is imperative so they are not negligent in worldly matters. According to Amran Waly, as a media of solitude to interact directly with Him, ratéb siribèe makes those who practice would not forget their creator. It is often referred to the recitation of Tawhîd-Tashawuf to cleanse the heart from feeling proud of what Allah, the Almighty, has entrusted to humans such knowledge, wealth, position, and other statuses. In fact, all prestige belongs to Allah, the Almighty, and those are bestowed to human beings to be used in accordance with His pleasure by showing gratitude, benefiting their family, and becoming His servant on the earth. ${ }^{24}$ Amran Waly voiced that human could reach anything; yet, they should never forget that Allah, the Almighty, remains priority to be remembered at any time. ${ }^{25}$

Amran Waly clarified that ratéb siribèe was not the name of a new tariqa being accused by some dayah 'ulamâ' of Aceh. The word siribèe (a thousand) was just a mere name. He explained that ratéb siribèe had no limit. To make it catchy, Amran Waly termed siribèe in such activity. Therefore, ratéb siribèe is not limited to one thousand dhikrs; it can be more than that. This is accordance with the words of Allah, the Almighty, as He said in the Quran Surah al-Ahzâb: 41, "Oyou, who have believed, remember Allah with much remembrance."26

Amran Waly divided the dhikr activities into four categories - ma'al ghafiyâ (careless), ma'alyaqdhah (awaken), ma'al hudhur (conscientious), and ma'al ghaibah (defenselessness). The first dhikr is doing dhikr by using tongue only, while the second dhikr is higher than previous one; beside to using tongue, it is accompanied with comprehending the meaning of $d z i k r$ sentence through the heart of the performers, although the performers sometimes think other matters. The third categorize is doing dhikr with full attention. The performers would not think other matters, including their family or property. The last dhikr mentioned is when the performers see nothing in their dhikr, but Allah, the Almighty. The nûr (light) of Him is overflown within them. ${ }^{27}$ Amran Waly also coined that dhikr possessed many benefits. One of which would be dealt with in our affairs. If the dhikr has reached the third level, then, all wishes requested would be granted by Allah, the Almighty. In fact, in the fourth level, He would grant intentions of the performers. Therefore, by ratéb siribèe, Amran Waly suggested to remember Allah, the Almighty, all the times by doing dhikr and increasing it gradually. As a result, the performers become qualified human beings and true believers in Allah, the Almighty ${ }^{28}$ However, he also stated that before committing dhikr, the performers might have faith that they were abject slaves having many sins and

${ }^{24}$ al-Khalidy.

${ }^{25}$ Amran Waly al-Khalidy, Risalah Tauhid Tasawuf Dan Tauhid Sufi, vol. 1 (Pawoh: MPTT, 2020); Amran Waly al-Khalidy, Risalah Tauhid Tasawuf Dan Tauhid Sufi, vol. 2 (Pawoh: MPTT, 2020).

${ }^{26}$ Abdul Rahman As-Sa'dy, Tauhid (Riyadh: Daar al-Qasim, 1923).

${ }^{27}$ Amran Waly al-Khalidy. "4 Kategori Berzikir" (YouTube: MPTT Nusantara, 2019), https:// youtu.be/a4_PLUifEcQ.

${ }^{28}$ al-Khalidy. 
mistakes and they should feel as the foulest of all creatures, even by those who had ever done faults. By doing so, ratéb siribèe would act as a vehicle that taking its performers flying a heart from khalqiya (mortal realms) to ulûhiyya (afterlife).

Through MPTT and ratéb siribèe, Amran Waly politely pulled his people from worldly negligence and deviated from the sacred as a human being of Allah, the Almighty. This action was quite apparent when he initiated ratéb siribèe. Amran Waly stressed that the integrations of Sufism tenet he developed would free the performers' thoughts of doing something, which was contrary to the qadr (fate) of the provisions of Allah, the Almighty. Thus, the performers would have a true monotheism since they had gotten the inner light to dispel inner shirk.

The religious teachings were increasingly felt down to the ground when tens of thousands of Muslims were always involved in such grand dhikr meetings. Not only did the dhikr events involve Southeast countries like Malaysia, Brunei Darussalam, Singapore, Cambodia, Thailand, Philippines, but those also engaged other countries such as Morocco, Egypt, South Africa, Algeria, Turkey, Tunisia, and even Hungary. Observers and researchers assumed that the integration of Sufism tenet developed by Amran Waly in Indonesia and parts of the world brought promising results, although various debates within communities in Aceh upon the tenet.

\section{The Communities' Responses to MPTT and Ratéb Siribèe}

On the regard to the communities' responses to MPTT, firstly, it should be started with several understandings of tawhîd, which became as the foundation of MPTT and ratéb siribèe. Those were then questioned by 'ulamâ'. Based on a muzakarah to discuss the issue, they agreed that the tenet developed by Amran Waly was misguided. ${ }^{29}$ Meanwhile, among communities, one of verse excerpt of Surah al-Ikhlas, huwa (he) in Qul huwa Allâhu ahadun, referred the dhamîr (pronoun) to Prophet Muhammad PBUH as al-Insân al-Kâmil. This perception became a debate among Acehnese 'ulamâ'. ${ }^{30}$

A charismatic 'ulamâ' from Bireuen, North Aceh, Abu Tu Min Blang-Bladeh, also delivered his comment towards the tenet developed by Amran Waly and its sources, particularly the interpretation of the huwa. He believed which had deviated the Islamic 'aqîdah and it was considered heretical and misleading in the science of Sufism. ${ }^{31}$ Besides, Abu Yusuf Ali, the MPU vice Head of Lhokseumawe City, detailed that the huwa had two meanings - isyari and itltifa'i. The first implies that dhamîr of huwa refers to Allah, the Almighty, who created nûr (lights) of Prophet Muhammad PBUH, while the second implicates that the huwa refers

${ }^{29}$ MDSD, "Majelis Pengkajian Tauhid Tasawuf: Akankah Diterima Ulama?," Media Dakwah Santri Dayah, March 2010, p. 2.

${ }^{30}$ MDSD, pp. 3-4

${ }^{31}$ Misbah, Gerakan Dakwah Sufistik: Majelis Pengkajian Tauhid-Tasauwuf Abuya Syeikh Amran Waly Al-Khalidi di Aceh, p. 180. 
to the next verses of al-Ikhlâsh, al-Ahadun, al-shamadu, lam yalid wa lam yûladu, walam yakun-lahu kufuwan ahadun. ${ }^{32}$

Related to the arguments, Amran Waly in his book clarified that the interpretation of the huwa was forwarded from a book content composed by a prominent scholar in Sufism, Shaykh 'Abdul Karîm al-Jîlî. The book entitled al-Insân al-Kâmil fì Ma'rîffat al-Uwakhir wa al-Uwail revealed that the dhamîr of huwa returned to the word qul meaning al-Insân. Based on the interpretation of al-Isyari (something that can be defined), al-Insân could led to haqiqa (truth), one of the four stages in Sufism, sharia (exoteric path), tharîqa (esoteric path) and ma'rîfat (final mystical knowledge). ${ }^{33}$ Yet, 'ulamâ' in North Aceh criticized the book. The Head of HUDA of Province Aceh in 2009, Abu Ibrahim Bardan as known as Abu Panton asserted that several surahs interpreted by Amran Waly could formulate ummah inmisunderstanding and ultimately it led to digression of 'aqîdah. ${ }^{34}$ Therefore, tashawuf should not be taught to common people. Apparently, it could damage 'aqîdah leading to a misinterpretation among them. ${ }^{35}$

Furthermore, MPU committees of North Aceh through a discussion on 26 November 2009 agreed that another book by Amran Waly, Sekelumit Penejelasan tentang Ajaran Tauhid Tasawuf Abuya Shaykh Haji Amran Waly al-Khalidy dan Penjelasan Beberapa Ucapan 'Abdul Karîm al-Jîlî dalam Kitabnya al-Insan al-Kamil fi Ma'rifat al-Uwakhir wa al-Uwail (A Brief Explanation of Tawhîd Teachings of Amran Waly and Explanations of Several Speeches of 'Abdul Karîm al-Jîlî) in his Book had deviated from the true teachings of Islam. They issued a fatwâ that the explanations written in that book along with the teachings promoted by 'Abdul Karîm al-Jîlî were haram. In the same time, the committees also banned the distribution of the book since it could misunderstand by common people and harm their faith. ${ }^{36}$ Nevertheless, similar with HUDA, the MPU committees of Lhokseumawe City could not take their action related to the Sufism tenet of Amran Waly. According to the MPU Head of Lhokseumawe City, Abu Bakar Ismail, only Provincial MPU has a right to issue a fatwâ on a religious issue. However, as a representative of regency level, MPU of Lhokseumawe City had submitted a request to Provincial MPU to explain the tenet of Amran Waly, although there has been no response at all from the authorized one. Consequently, the integrations of the tenet, discussion of MPTT and ratéb siribèe, are not banned. Even a

${ }^{32}$ Abu Yusuf Ali, personal communication, 17 March 2020.

${ }^{33}$ Amran Waly al-Khalidy, Konsep Ajaran Tasawuf Majelis Pengkajian Tauhid Tasawuf (Pawoh: MPTT, 2013), p.1.

${ }^{34}$ MDSD, "Majelis Pengkajian Tauhid Tasawuf: Akankah Diterima Ulama?”, pp. 2-5.

${ }^{35}$ al-Khalidy, Konsep Ajaran Tasawuf Majelis Pengkajian Tauhid Tasawuf, p. 9.

${ }^{36}$ Majalah Santri, "MPU Larang Peredaran Buku Syeikh Haji Amran Waly," Majalah Santri, December 2009; Misbah, Gerakan Dakwah Sufistik: Majelis Pengkajian Tauhid-Tasauwuf Abuya Syeikh Amran Waly Al-Khalidi di Aceh, p. 176. 
great dhikr was organized in the Islamic Center of Lhokseumawe City, which was facilitated by the city mayor in $2018 .^{37}$

For the common people in Bireuen Regency, North Aceh, Lhokseumawe City, and Langsa City, the effect of controversy on the Sufism tenet of Amran Waly was in low pressure. They, in general, would follow the argument of their Islamic teachers. If the teachers were pro to the Sufism tenet of Amran Waly, they would accept it. Meanwhile, they would reject the tenet if their teachers did not accept it. ${ }^{38}$

Nonetheless, discussing the concept of the tenet, the understanding of al-Insân alKâmil, the classical Sufism doctrines, is a form of wahdah al-wujûd. The classical Sufism doctrines are a full manifestation of wahhdah al-wujûd developed by Shaykh 'Abdul Karîm al-Jîlî and wah̆dah al-wujûd developed by Ibn 'Arabî, a great imam of Sufism in Arabian countries. Both perceived that the divinity of Allah, the Almighty, exceeds other creatures. As a result, Prophet Muhammad PBUH, turned into the representative of al-Insân al-Kâmil, a perfect human being. ${ }^{39}$ In fact, this view is not in line with Islamic Sharia, as said by Abu Panton. The same thing was in effect to several interpretations in the book composed by Amran Waly. He alleged that those were flummoxing and could damage the 'aqîdah of common people.

However, Amran Waly contended that his teachings had a strong foundation sourced from the contents written by Shaykh 'Abdul Karîm al-Jîlî who has been recognized by Muslims over the world. As explained in the book al-Kahfi war-Rakimu, he had produced dozens of Sharia books compiled from other 'ulamâ'. Based on that context, the TawhîdTashawuf practiced by Amran Waly is advantageous to eliminate the heart's connection to other than Allah, the Almighty. It makes the followers praying to Him fervently, of course, after understanding the true 'aqîdah and the Sharia laws. Amran Waly defended that the teachings would not damage the 'aqîdah, yet, those made it better. Therefore, Muslims who already understood the teachings, obligatorily, they should learn more for Sufism teachings, so the practice of which would not be fruitless. Additionally, the actualization ideas of wahdah al-wujûd in the classical Sufism doctrines, according to Amran Waly, require to be re-interpreted in simple language and Islamic contemporary context. In the end, it perfects the tawhîd of a Muslim as the main foundation in religion. ${ }^{40}$

Correspondingly, Tgk. Mahfudh expressed that the Sufism teachings developed by Amran Waly in substance did not contradict the essence of Islamic teachings. However,

${ }^{37}$ Abu Bakar Ismail, personal communication, 27 March 2020.

${ }^{38}$ Sya'bi, personal communication, 28 March 2020; Jamaluddin, personal communication, 18 March 2020.

${ }^{39}$ Muhibuddin Waly al-Khalidy, Ulama Aceh Dan Peranannya Dalam Pembangunan Pendidikan (Jakarta: IAIN Syarif Hidayatullah, 1996), p. 10.

${ }^{40}$ al-Khalidy, Konsep Ajaran Tasawuf Majelis Pengkajian Tauhid Tasawuf, p. 10; Amsal Bakhtiar, Tasawuf \& Gerakan Tarekat (Bandung: Angkasa, 2003), pp. 1-23. 
some charismatic 'ulamâ' of Aceh, particularly from northern and eastern ones, opposed that the teachings tended to the concept of al-Insân al-Kâmil to common people. Those who did not understand comprehensively towards the concept would be misguided in an improper interpretation of the nature of the God. ${ }^{41}$

In addition, Djamaluddin Waly labelled the Tawhîd-Tashawuf developed by his young brother could cause idolatry or apostasy, even exceeding Jews and Christians. ${ }^{42}$ This was depicted in his book, Ajaran-ajaran yang Menyimpang (Misguided Teachings)", which was addressed to MPTT. It was distributed widely among Acehnese people. The distribution of the book, however, indirectly, created a disharmony between Muslims in Aceh, even it triggered criminal acts, in Matang, the Regency of Bireuen, for instance. The effect of fatwa conveyed by Djamaluddin Waly made half of communities, specifically alumni of dayah (Islamic traditional school), perceived the Sufism tent developed by Amran Waly needed to be limited. It means those who are the followers of MPTT should be restricted. One case ever occurred in Bireuen, where a khatib (Islamic preacher) was banned to lead the Friday prayer.43

The activities of MPTT and ratéb siribèe were evaluated within other regions of Aceh. The communities of Lhokseumawe City, for example, were pro to those. They were mostly common people and alumni of Labuhan Haji dayah led by Amran Waly. Meanwhile, those who were cons to MPTT and ratéb siribèe were communities who stayed near dayah in Pidie, Pidie Jaya, Bireuen, North Aceh, Lhokseumawe City, and East Aceh. Accordingly, most of them chose to join the council of TASTAFI (Tashawuf, Tawhîd and Fiqh) initiated by Tgk. Hasanoel Basry known as Abu Mudi Mesra. ${ }^{44}$ In one religious discussion, he responded a question thrown by a congregation related to MPTT. He wondered the naming of MPTT compared to his council, TASTAFI, since both had the term Tawhîd-Tashawuf. Abu Mudi Mesra advised his followers not to define the name by their own. They should ask something to its founder by themselves. ${ }^{45}$ In the meantime, intentionally, various dayah in northern and eastern Aceh like al-Aziziyah Dayah of Samalanga led by Abu Mudi Mesra, Madinatuddiniah Babussalam Dayah led by Abu Tu Min Blang-Bladeh and others established their affiliations to prevent the dissemination of MPTT and ratéb siribèe within the communities.

This big conflict between dayah 'ulamâ' and MPTT followers was commented by Hamzah. According to him, the different opinions between Sharia 'ulamâ (refers to dayah 'ulamâ') and Sufi 'ulamâ (refer to MPTT scholars) indicated a struggle for influence over the authorities. In Aceh, Sharia 'ulamâ dominated in various activities and those were close to the authorities, in compiling several canons and other policies in Aceh, for instance.

${ }^{41}$ Mahfudh, personal communication, 12 March 2020.

${ }^{42}$ al-Khalidy, Konsep Ajaran Tasawuf Majelis Pengkajian Tauhid Tasawuf, p.13.

${ }^{43}$ Sya'bi.

${ }^{44}$ Fakhrurrazi, personal communication, 19 March 2020.

${ }^{45}$ Hasanoel Basry, "Apa itu Aliran Islam Nusantara Serta MPTT" (YouTube: Love Aceh, 2018), https://www.youtube.com/watch?v=BgkracE1UjM. 
Their role in ratifying religious issues, precisely regarding Islamic Sharia law, has quite a strong influence, not to mention their buff towards Sharia institutions, such as Wilayatul Hisbah (Sharia Police) and Baitul Mal (House of Treasury). The conflict could happen due to balancing their position towards the rapid movement of MPTT scholars who were regarded as the threat for their position. In fact, Sufi scholars, which in this case, was represented by MPTT led by Amran Waly, has a small portion with the authorities. Even in each of their big agendas, the Sharia institutions were scarcely involved. ${ }^{46}$

From the aforementioned discussion, the pros and cons to the Sufism tenet developed by Amran Waly could be formulated in the following chart.

Table 1.

The Pros and Cons towards the Sufism Tenet Developed by Amran Waly

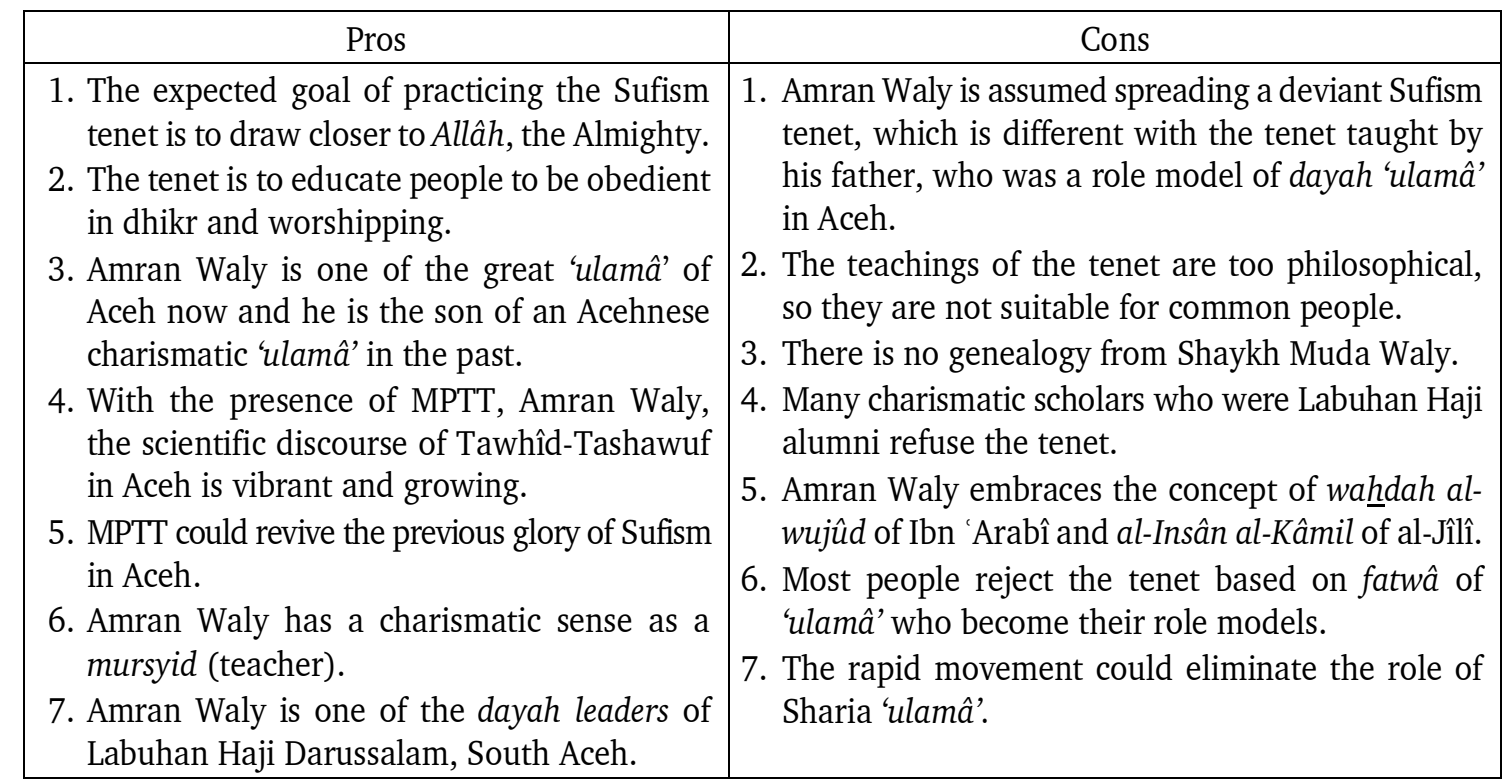

Apart from the pros and cons discoursed above, Hasan Muarif Ambary professed that religious issues, mainly the relationship of humans and their God, as developed by alJîlî and followed by Hamzah Fansuri, Syamsuddin as-Sumatrani and Amran Waly, should be put in the category of wahdah al-wujûd, requiring the followers 'enter' the teachings in depth. ${ }^{47}$ For that reason, to understand the meaning of Sufism tenet developed by Amran Waly through his integrations - MPTT and ratéb siribèe, the process of tariqa is the 'gate' to practice his teachings to pass the level of-al-Aqaba (obstacle) and become a true Sufi.

${ }^{46}$ Hamzah, personal communication, 3 March 2020.

${ }^{47}$ Hasan Muarif Ambary, "Ulama Besar dan Kualitas Intelektualnya," in Tracing Back the Paths of Hamzah Al-Fansury: An Intellectual, a Sufi and a Man of the Letters (Jakarta, 2013). 


\section{CONCLUSION}

The basis of Sufism tenet developed by Amran Waly was claimed as a tenet instructed by Shaykh 'Abdul Karîm al-Jîlî. In Aceh, it had been developed by Hamzah Fansuri and his pupil, Syamsuddin as-Sumatrani. The tenet, however, was considered heretical since it had the concept of wahdah al-wujûd. Amran Waly then attempted to reconstruct the context by reinterpreting earlier Sufism tenet his students in his dayah and other communities. He believed that his developed tenet had one goal, making a Muslim believed in Allah, the Almighty in a true understanding of Tawhîd-Tashawuf. Therefore, he established a social organization named MPTT to accommodate the needs of 'ulamâ', umara and ummah in discussing and disseminating the teachings of Tawhîd-Tashawuf. This organization even invited a number of its congregations from various countries, which made it popular within international Muslims. As a part of MPTT's activity, ratéb siribèe became the icon of Amran Waly's teachings. Its foundation is to support the worshippers eliminating their inner shirk and getting close to Allah, the Almighty.

However, the teachings developed by Amran Waly were not accepted by every party. In the northern and eastern of Aceh, many 'ulamâ' refused it by leaving reasons that the tenet was different with the ones taught by Amran Waly's father, Shaykh Muda Waly. Some believe the tent was tough to be understood by common people, so it could lead the followers to a misguided belief. As a result, many communities in those areas bought the fatwâ delivered by their 'ulamâ'. On the contrary, many people within western and southern Aceh supported the tenet developed by him. Most of them believed the tent is to educate them to be obedient in dhikr and worshipping. In addition, considering he is the son of a charismatic 'ulamâ' and the Head dayah of Labuhan Haji Darussalam, his followers, without no doubt, have a similar appeal to regard him as a real mursyid. Nevertheless, the debates still take place since MPUAceh as the authority did not do actions or gave mediation to all parties confronted. This condition should be taken into account; hence, there would be no incident as happened in 2009, when ratéb siribèe as the activity of MPTT was seized by the communities of northern and eastern Aceh.

\section{References}

Al-Khalidy, Amran Waly. Risalah Tauhid TasawufDan Tauhid Sufi. Vol. 1. Pawoh: MPTT, 2020. Al-Khalidy, Amran Waly. Risalah Tauhid TasawufDan Tauhid Sufi. Vol. 2. Pawoh: MPTT, 2020.

Al-Khalidy, Amran Waly. "Aceh, Masyarakatnya, Dan Langkah-Langkah Yang Diperjuangkan Dalam Ajaran Tauhid Tasawuf Bagi Masyarakat." In Maulid Nabi Besar Muhammad SAW 1437, 1-12. Pawoh, 2016.

Al-Khalidy, Amran Waly. Konsep Ajaran TasawufMajelis Pengkajian Tauhid Tasawuf. Pawoh: MPTT, 2013. 
MIQOT Vol. 45 No. 1 January-June 2021

Al-Khalidy, Muhibuddin Waly. Ulama Aceh Dan Peranannya Dalam Pembangunan Pendidikan. Jakarta: IAIN Syarif Hidayatullah, 1996.

Ambary, Hasan Muarif. "Ulama Besar Dan Kualitas Intelektualnya." In Tracing Back the Paths of Hamzah Al-Fansury: An Intellectual, a Sufi and a Man of the Letters. Jakarta, 2013.

Al-Sa‘dy, ‘Abd al-Rahmân. Tauhî̂d. Riyâdh: Dâr al-Qâsim, 1923.

Bakhtiar, Amsal. Tasawuf \& Gerakan Tarekat. Bandung: Angkasa, 2003.

Basry, Hasanoel. “Apa Itu Aliran Islam Nusantara Serta MPTT.” YouTube: Love Aceh, 2018.

Firdaus. "Meretas Jejak Sufisme Di Nusantara." Al-Adyan: Jurnal Studi Lintas Agama 13, no. 2 (2018): 303-37.

Ichwan, Moch Nur. "Neo-Sufism, Shari'atism, and Ulama Politics: Abuya Shaykh Amran and Tauhid-Tasawuf Movement in Post-Conflict Aceh." In Islam, Politics and Change: The Indonesian Experience After the Fall of Suharto. Leiden: Leiden University Press, 2016.

Ja'far, Ja'far. Gerbang Tasawuf: Dimensi Teoretis Dan Praktis Ajaran Kaum Sufi. Medan: Perdana Publishing, 2016.

Ja'far, Ja'far. Warisan Filsafat Nusantara: Sejarah Filsafat Islam Aceh Abad XVI-XVII M. Banda Aceh: PeNA, 2010.

Kahar, Syadidul. "Dynamics of the Intellectual Tradition of Ulama Dayah Aceh." Lakhomi Journal Scientific Journal of Culture 2, no. 1 (2021), 46-53.

Kloos, David. "Aceh: History, Politics and Culture." Pacific Affairs 86, no. 1 (2013), 193-95.

Manan, Abdul. "The Influence of Tarekat Syattariyah toward Political and Social Aspects in the Regency of Nagan Raya, Aceh-Indonesia." International Journal of Advanced Research 5, no. 7 (2017): 258-67.

Manan, Abdul, and Fauzi Ismail. Syari'at Islam Di Aceh: Realitas Dan Respon Masyarakat. Banda Aceh: Ar-Raniry Press, 2014.

MDSD. "Majelis Pengkajian Tauhid Tasawuf: Akankah Diterima Ulama?." Media Dakwah Santri Dayah, March 2010.

Miles, Matthew B., and A. Michael Huberman. An Expanded Source Book: Qualitative Data Analysis. 2nd ed. California: SAGE, 1994.

Misbah, T. Lembong. Gerakan Dakwah Sufistik: Majelis Pengkajian Tauhid-Tasauwuf Abuya Syeikh Amran Waly Al-Khalidi Di Aceh. Yogyakarta: UIN Sunan Kalijaga, 2016.

MPTT. Ministerial Decree of the Establishment of Majelis Pengkajian Tawhid Tasawwuf(2016).

MPTT. Notarial Deed of the Establishment of Majelis Pengkajian Tawhid Tasawwuf, Pub. L. No. 14 (2004).

Musliadi. Abuya Syekh Muda Waly Al-Khalidy (1917-1961 M) Syekhul Islam Aceh: Tokoh Pendidikan Dan Ulama Arif Billah. Banda Aceh: Yayasan PeNa, 2017.

Nur, Syaifan. "Dialektika Filsafat Islam Sufistik Wujuddiyah Di Indonesia." Refleksi: Jurnal Filsafat Dan Pemikiran Islam 17, no. 1 (2017): 43-60. 
Rusdiyanto, and Musafar. "Ajaran Wujudiyah Menurut Nuruddin Ar-Raniri." Potret Pemikiran 22, no. 1 (2018): 1-10.

Salim, Arskal. "'Sharia from below' in Aceh (1930s-1960s): Islamic Identity and the Right to Self determination with Comparative Reference to the Moro Islamic Liberation Front (MILF)." Indonesia and the Malay World 32, no. 92 (2004): 80-99.

Santri, Majalah. "MPU Larang Peredaran Buku Syeikh Haji Amran Waly." Majalah Santri, December 2009.

Serambi News. "Bangkitnya Ajaran Kesufian Nusantara." Serambi News, 2017.

Serambi News. "Menyatukan Ummat Melalui Tauhid Dan Tasawuf." Serambi News, 2017.

Wasino, Endah Sri Hartatik, Nina Witasari, Muhammad Iqbal Birsyada, Balraj Singh, and Fitri Amalia Shintasiwi. "A Historical Perspective of Sufism Networking in Asia: From India to Indonesian Archipelago." PalArch's Journal of Archaeology of Egypt/Egyptology 17, no. 3 (2020): 761-74. https://doi.org/https://doi.org/10.48080/jae.v17i3.169.

“4 Kategori Berzikir.” Indonesia: MPTT Nusantara, 2019. 